\title{
A STUDY TO ASSESS THE EFFECTIVENESS OF STRUCTURED TEACHING PROGRAMME (STP) ON KNOWLEDGE REGARDING ZIKA FEVER AMONG STAFF NURSES IN MGMCRI, AT PUDUCHERRY. \\ *Anitha.B, ** Annie Annal.M
}

\section{Abstract:}

Objectives: To evaluate the effectiveness of Structured Teaching Programme (STP) on knowledge regarding Zika fever among Staff Nurses in MGMCRI at Puducherry. Materials and Methods of Study: Preexperimental (one group pre-test and post-test research design) was used. Results: The findings of the study revealed that post-test mean Knowledge score was higher than the pre-test mean score. Thus the difference in the level of knowledge was found to be significant at $p<0.001$ level. Conclusion: This Study concluded that the Structured Teaching Programme was effective to improve the knowledge of Staff Nurses.

Keywords: ZIKA Fever, Structured Teaching Programme

\section{Introduction}

Zika fever is currently one of the most important emerging viral diseases in the world. Recently, it has caused outbreaks and epidemics, and has been associated with severe clinical manifestations and congenital malformations 2. On February 1st 2016, the WHO declared the current Zika virus outbreak an international public health emergency 5.Zika virus, as of now, has no specific treatment in terms of vaccination or medication. But it can be prevented from happening or re-occurring health problems by implementing educational programs, developing policies, administering services and conducting. India needs to be particularly conscious about the spread of the disease since the mosquito that carries the virus actually thrives in the country ${ }^{1}$. Raising the knowledge level of Nursing staffs, who provide health care at various level of health system, is important to take initial action to prevent emerging illness from outbreak of Zika virus in India.

\section{STATEMENT OF THE PROBLEM:}

"A Study to assess the Effectiveness of Structured Teaching Programme (STP) On Knowledge regarding Zika Fever among Staff Nurses in MGMCRI, at Puducherry".

\section{OBJECTIVES OF THE STUDY:}

- To assess the level of knowledge regarding Zika fever among Staff Nurses in MGMCRI, at Puducherry.

- To evaluate the effectiveness of Structured

Teaching Programme (STP) on knowledge regarding Zika fever.among Staff Nurses in MGMCRI at Puducherry.

- To find out the association between the level of knowledge and selected demographic variables. 


\section{Methodology:}

Pre experimental with One Group pretest- post- test- Design. The study was conducted in Mahatma Gandhi Medical College and Research Institute, Puducherry. The target population for the study was Staff Nurses.

The sample was collected using Nonprobability convenience sampling method. It consisted of 50 Staff Nurses. The result were computed by using descriptive and inferential statistics

Description of the Tool: The data were collected by Structured Interview Questionnaire. The tool consisted of Section A and B.

Section A: Demographic variables of the Staff Nurses consisted of age, gender, religion, marital status, educational qualification, year of working experience, Family income, area of living, exposure to previous information and source of information.

Section B: Structured Interview Questionnaire which consists of definition, incidence, mode of transmission, clinical manifestation, diagnostic study, treatment, preventive measures and complication of Zika fever

\section{RESULTS:}

Level of Knowledge regarding Zika

fever among Staff Nurses in pre-test and post-test

\section{Knowledge Level}

100

50

0

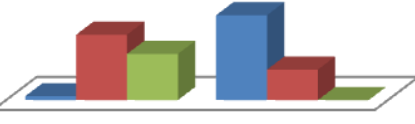

pre test post test

$\square$ adequate $\square$ moderate $\square$ inadequate

Comparison of pre and post test, mean level of knowledge regarding Zika fever among Staff Nurses

$\mathbf{N}=\mathbf{5 0}$

\begin{tabular}{|l|c|c|c|c|c|c|c|}
\hline S.No & $\begin{array}{c}\text { Level of } \\
\text { knowledge }\end{array}$ & Mean & $\begin{array}{c}\text { Std. } \\
\text { Deviati } \\
\text { on }\end{array}$ & $\begin{array}{c}\text { Std. } \\
\text { Error } \\
\text { Mean }\end{array}$ & $\begin{array}{c}\text { Differe } \\
\text { nce in } \\
\text { means }\end{array}$ & t-test & p-value \\
\hline 1. & Pre -test & 7.03 & 3.000 & 0.548 & & & \\
2. & Post- test & 18.30 & 3.798 & 0.693 & -11.267 & -17.096 & $<0.001$ \\
\hline
\end{tabular}

The findings of the study showed that posttest mean knowledge score was higher than the pretest mean score. Thus the difference in the level of knowledge was found to be significant at $p<0.001$ level.

\section{RECOMMENDATIONS:}

- The study can be replicated with large sample for better generalization. 
- There should be mass education and group discussion for health care professionals regarding Zika fever.

- There should be periodical awareness programme regarding Zika fever among health care professionals.

- Study can be done to determine the effectiveness of Structured Teaching programme on knowledge regarding Zika fever among selected rural areas.

\section{CONCLUSION:}

The main study was done to determine the effectiveness of Structured Teaching programme (STP) on Knowledge regarding Zika fever among Staff Nurses in MGMCRI, at Puducherry. The study findings provided the statistical evidence which clearly indicates that Structured Teaching Programme can be implemented as teaching strategy to promote the level of knowledge.

\section{REFERENCES}

1. Hayes EB (2009) text book of "Zika virus outside Africa" Suvan publications;15(9): pg no.1347-1350

2. Lucchese G, Kanduc, (24 March 2016)D Zika virus and auto immunity, Autoimmune Rev.

3. Faye 0,et al. Molecular Evolution of Zika virus during Emergency in the 20(th) century. Plos Negl Trop Disease pp.2014;8 e 2636

4. Musso D.Gubler D.J Zika virus. Clim Microbial Rev 2016 July 29(3):pp.487524

5. Plourde AR. Bloch E.M A Literature Review of Zika Virus. Emergency Infectious Disease 2016 July15;22(7)

6. Lanicott RS, Lambert AJ Holodony M.Saveedra S,Signor Ldel C, Phylogency of Zika virus in Western Hemisphere,2016 Emergency Infectious Disease 2016 May 22(5):pp.933-935

\section{PERITONITIS "HOT BELLY"}

Risk Factors

- Abdominal Surgery

- Ectopic Pregnancy

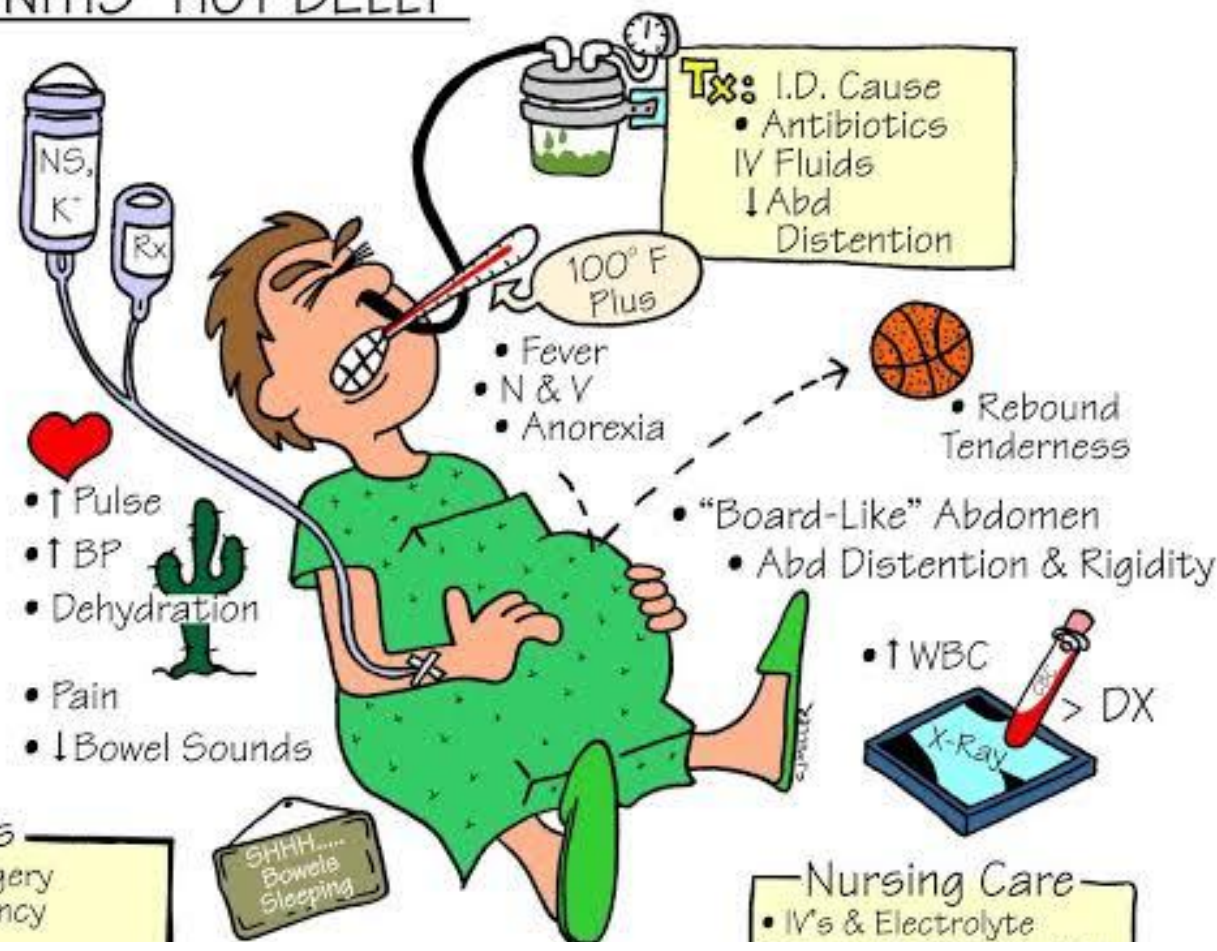

